Journal of Educational Social Studies
JESS $9(2)(2020): 36-43$
UNNES

\title{
The Integration of Living Environmental Education in the Behavior of High School Students in Brebes Regency
}

\author{
Karyono Budi Leksono $^{1 凶}$, Dewi Liesnoor Setyowati ${ }^{2}$ Puji Hardati $^{2}$
}

${ }^{1}$ SMAN 1 Bumiayu Brebes, Indonesia

${ }^{2}$ Universitas Negeri Semarang, Indonesia

\begin{tabular}{l}
\hline Article Info \\
\hline History Articles \\
Received: \\
9 September 2020 \\
Accepted: \\
6 November 2020 \\
Published : \\
17 December 2020 \\
\hline Keywords: \\
Integration, Living \\
Environmental \\
Education, Learners' \\
Behaviors
\end{tabular}

\begin{abstract}
Life environment education gains the main priority for formal education. For school stakeholders, this condition should be responded to immediately. Schools have to struggle to improve their learners' environmental awareness. This research describes and analyzes the Living Environmental education policy, its integration to a geographic lesson, and learners' environmental awareness behaviors of Senior High Schools in Brebes. This research is qualitative. The data were collected by interviewing, observing, and studying the document. The applied data analysis stages were data reduction, display, and conclusion. The findings showed that 1) the Living Environmental education policy was determined by the school since there were no obligated rules from the government. 2) Living Environmental education integration had been promoted well in a geography lesson. It was realized into learning instrument administration and the learning process. This life environment education could be integrated into almost all basic competencies of all geographic materials. 3) learners were aware of a better living environment. They were aware and could understand the problems and negative impacts. In addition to these, learners also acted and were committed to keeping their life environment
\end{abstract}

\footnotetext{
$\triangle$ Correspondence address:

Jalan P. Diponegoro No.2, Bumiayu, Brebes, Jawa Tengah

E-mail: budyleksono@gmail.com
} 


\section{INTRODUCTION}

One of these discourse's main issues is a better living environment for regional, national, and international levels. People's awareness as ecological creatures in the ecosystem makes them considering several environmental factors in each activity or development. Living environment awareness should be instilled for every person through education, started from early childhood age until higher education levels (Setyowati, et.al, 2014). Low individual awareness of the natural environment is frequently found in every Indonesian citizen. Humans that live along together have feedbacks and need each other. Every individual should realize the importance of keeping, maintaining, and preserving the natural living environment.

The regions' advancements in Indonesia also trigger various disasters or environmental problems such as landslide, fire forest, material disadvantage, and human victim (Kementerian Lingkungan Hidup, 2011). These environmental damage causes are due to the increased population number and life-standards. Thus, there is a correlation between population and environmental problems (Hardati, et.al, 2015). Natural damages could be caused by nature or the natural exploiting behavior of humans. The increasing rate of natural damage and environmental pollution is caused by humanactivity rubbish (Hardati and Setyowati, 2018).

This living environment education research was developed due to low understanding and skill to keep the living environment. It made the society influenced by irresponsible parties while establishing a harmonious community arrangement. This lack of awareness triggered humans to merely fulfill their life necessity and satisfaction by making the universe a meant to satisfy. Nature also needs human roles to develop continuously and to benefit humans' life and future generation. Humans take the benefits of nature without considering the negative impacts and the consequences. Nature supports humans' existence, but it suffers heavy damages, especially due to the development, attitude, behavior, and the unfriendly policy (Alikodra, 2017).

Living environment education is important to empower the society so that society will behave rationally and is responsible for managing environmental problems. Humans have both affection and cognition that should go together equally. Thus, they could promote a better reasoning process. However, dealing with environmental affection, responsibility character should be empowered first. It is important because living environment education should be started by having responsibility. Without appropriate mentality, all cognition and skills will not change any attitudes or behaviors. To trigger humans' awareness about their living environment, it should be started by making them aware (Setyowati et.al, 2014). When this process, the behavioral change, and the mindset occur, the living environment understanding, cognition, skill, and management could be improved.

Living environment education currently has not obtained an appropriate position. It is merely promoted dominantly in a non-formal educational setting while the formal education has not promoted it yet. This condition should be responded to immediately by educational stakeholders. The educational units or schools should plan further efforts to prepare the learners as social members. It has a purpose to improve their living environment awareness.

The integration of living environment education and formal education is a process to prepare better learners' reasoning skills. Thus, they could develop their personalities, environments, nation, and country. This integrating process is expected to create sensitive and aware learners about environmental problems.

Recent phenomena are mostly dealt with by the younger generation, the learners, such as poor environmental awareness inculcation. It could be seen from the poor learners' environmental awareness behaviors. They have not understood the complete environmental awareness values so that these are reflected in their behaviors. Some learners had 
environmental awareness because of their teachers' or schools' encouragements. On the other hand, several learners did not do so. It could be seen from several tables, chairs, and walls of lavatories had scratches. They were also found littering and improvident.

Their reasoning skills deal with how to respond to various environmental phenomena in daily life, especially in the context of the school's living environment. Besides, the integration process was assumed informative and different from one school to another school. Living environment awareness behaviors are closely correlated to learners' behaviors to preserve the surrounding environment. Thus, it could be seen from a Senior High School action to integrate this living environment education. This research described and analysed the living-environment education policy, its integration to the geographic lesson, and learners' environmental awareness behaviors of Senior High Schools.

\section{METHODS}

This research applied a qualitative research method. Three schools in Brebes regency participated in this research. They were Public 2 SHS Brebes, Public 1 SHS Bumiayu, and Public 1 Kersana SHS. The informants' main sources were the principles, the vices of principles, the living-environment executive program division chairman, and the twelfth graders of social science study departments.

The data were collected by interview, observation, and documentation from these schools. The applied analysis model was Mile and Huberman model with three steps: data reduction, display, and conclusion.

\section{RESULTS AND DISCUSSION}

\section{The Living Environmental Education Policy of the Senior High Schools in Brebes}

This model explains that a policy performance is influenced by inter-correlated independent variables, such as the basic size and the policy objective, the communication among the executive agencies, the characteristics of the executive agencies, the socio-economic and political environments, the executive tendency, and the resource capacity (Winarno, 2012).

The findings showed that the schools provided opportunities to make decisions from the government. There were also no requirements for the schools to apply certain regulations from the government or Ministry in integrating living environment education at schools. From the findings, Public 2 SHS Brebes and Public 1 Kersana SHS took the integrated policy. They realized it into an adiwiyata school program, also known as an empowerment school program, from the Ministry of Environment Forestry. The Public 1 Bumiayu SHS realized the policy decision into the action of reducing plastic rubbish. It was a part of the character educational empowerment program by emphasizing the Ministry's environmental care values.

The communication among the executive divisions about the school policy integration process was realized into regular socialization agenda. It had a purpose to ensure the objective and the mechanism of the program running properly for all participating parties. These schools' findings showed the regular socialization process of the integrated living environment education in various opportunities. It was done by the principles and the school stakeholders. The socialization was done in a meeting agenda between the policy-executive agency and the school members. They were such as the teachers or the learners. In Public 2 SHS Brebes and Public 1 Kersana SHS, the living environment policy socialization was done through official meetings between the teachers and the school employees.

On the other hand, the socialization for the learners was also conducted regularly during flag ceremonies and Friday-clean actions. Public 1 Bumiayu SHS also socialized the policy through official meetings between the teachers and school members. The learners' socialization was done regularly during flag ceremonies, Friday-clean actions, and mujahadah on Thursdays. 
The characteristics and executive structures of these schools showed that excellent living environment education policy promotion. Each school established an executive team and cooperative group. They were declared in a principal decree and had their main job descriptions written there. Every executive team member and the cooperative team had different job descriptions to carry out the schools' program.

Therefore, the socio-economic and political situations at schools were conducive. It was supported by geographical, socio-economic, and political situations of Brebes regency to integrate the living environment education policy at schools. Brebes regency had a moderate human resource development index, a moderate economic growth, and a standard generated revenue. One of Brebes' tradition, ngasa, is a native Javanese culture resource. It is hereditarily inherited in Brebes (Fadillah and Supriyanto, 2020).

Other findings showed that these schools' responses and the school members' acceptances were excellent. It could be seen from the spirit and enthusiasm of the executive agencies and the school learners/ Meanwhile, the capacity and resources showed there were task groups within the executive agencies. It proved that all schools involved the existing resources. They invited the school members to actively participate in carrying out the school program and the living environment education. The task groups were such as groups of garbage banks and Friday-clean actions.

The findings strengthened the previous studies conducted by Jackson, et.al (2016). He found that formal education played the main role in developing living environment awareness behavior. Formal education, such as Senior High School, applied the policy objective through concepts or executive programs. Barkatin and Wijayanto (2016) also found that the principals' competencies, the educators, and educational staff could improve learners' active participation to preserve the environment. The principals' competencies had important roles in determining further living environment conceptual decisions.

\section{Living Environment Education Integration into Geography Lesson in Brebes Senior High Schools}

The finding showed that geography is a lesson of the Social Study department program. Geography is a closely related lesson to the living environment. Thus, it could be integrated into almost all basic competencies of a geography lesson. The finding was supported by a previous study conducted by Yli-Panula, Jeronen and Lemmentty (2019). He found that geographic educators could develop a living environment personality to reach the sustainable development objective. Guo, et.al (2020) also found that geography is a discipline that had strong synergy with environmental education.

A study conducted by Handayani, Wuryadi and Zamroni (2015), Wanchana, et.al (2019) and Irlansari and Hardati (2019) also found that environmental education could be integrated into school lessons. In this case, geography lesson was also considered as a social study science in the 2013 curriculum.

The living environment education integration in geography lesson was begun by planning. It was explained clearly and realized into several learning instruments, such as syllabus and lesson plan. The findings from these schools showed a one-page lesson plan policy. It extremely influenced the teachers to design their lesson plans. Using this lesson plan format, all geography teachers in these schools did not write the integration contents. The integration of living environment education was directly given by the teachers to the learners. They provided examples of living environment awareness behaviors during the teachinglearning activities. This finding was supported by Rezkita and Wardani (2018). He found that living environment education integration at schools could be done through planning, implementing, and evaluating the learning.

\section{Living Environment Awareness Behaviors of the SHS Learners in Brebes}


Generally, this behavior was excellently promoted in schools. The behavior was measured by some indicators. They understood environmental complexity, environmental impact risk understanding, environmental rescue action, and commitment to preserving the environment.

The learners' environmental complexity understanding dealt with recognizing and understanding environmental problems, especially environmental preservation. In this indicator, the learners were categorized as excellent. Their understanding level was proved by reaching $93.31 \%$ of these schools' informants in Brebes, as presented in Figure 1.

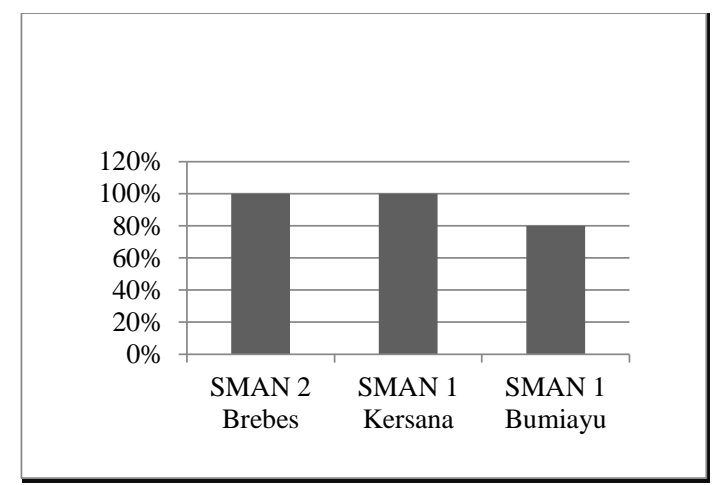

Figure 1. The Graphic of Environmental Complexity Understanding Percentage

Figure 1 shows that the Public 2 SHS and Public 1 Kersana SHS informants, 100\%, had understood the environmental complexity occurring in their schools. Meanwhile, in Public 1 Bumiayu SHS, only $80 \%$ of informants that already understood it. Both Public 2 SHS Brebes and Public 1 Kersana SHS had implemented the environmental education concept to adwiyata school program for a long time ago. They even ever became the national and province winners. The environmental education concept of Public 1 Bumiayu SHS was only conceptual empowerment that developed environmental awareness values. The informants mostly stated that their schools' environmental problems mostly dealt with environmental cleanliness and living environments treatment problems, such as understanding garbage and organic - non- organic screening managements and treating the plants in the classrooms.

Risk and environmental impacts should be understood. Most senior high school learners of the schools understood the risk and environmental impacts of reckless behaviors through media, education, and personal experience. Their understanding level was proved by reaching $90 \%$ of these schools' informants in Brebes, as presented in Figure 2.

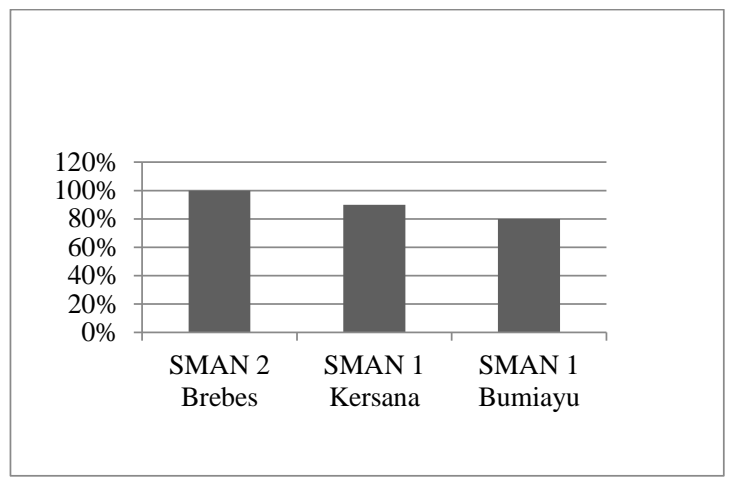

Figure 2. The Graphic of Environmental Impacts

Public 2 SHS Brebes has a high understanding of the learners' percentage about the environmental impacts, $100 \%$. It was due to its excellent adwitaya appreciative program. Moreover, the school was also rewarded as the selected adwiyata school nationally in 2018. The school had excellent environmental education inculcation through adwiyata school concept. Public 1 Kersana SHS learners had excellent environmental impact understanding with a percentage of $90 \%$. The school had successfully instilled environmental education through adwiyata school program. Moreover, in 2017, the school was rewarded as an adwiyata school in a Central Java province level.

Public 1 Bumiayu SHS learners had excellent environmental impact understanding with a percentage of $80 \%$. The school had just instilled environmental education through character education empowerment. This program took environmental care values and promoted a movement to reduce plastic usages called smansabum bye-bye plastic in 2019. The investigated schools had been aware of 
environmental impacts due to livingenvironmental ignorant behaviors. Therefore, most learners were aware of environmental preservation importance to avoid any negative experiences of such impacts, such as ignorant behavior, environmental preservation by planting trees, and rubbish or garbage management.

These behaviors and actions to save the environment had been performed by the learners. They managed and screened organic and non-organic garbages correctly, actively participated in preserving the environment, maintained the living environment based on the school program, warned those breaking the regulation, and provided good examples among learners to keep the school living environment. Public 2 SHS and Public 1 Kersana SHS learners had performed actions and countermeasures to save the living environment. They established an organic garbage fertilizer for plants.

The learners' commitment also showed that they were ready to keep their motivation and transfer their environmental care behavior for the sake of a better future living environment. This finding was consistent with Bloom's perspective, as quoted in Notoatmodjo (2017). He explained that knowledge is the lowest cognitive aspect, but it had important roles to construct individual behavior. Knowledge deals with any recognized matter or individual intelligence. It is obtained through experiences, training, and learning process. An individual's skills are mostly determined by his reading, writing, and computing skills in a learning process. However, he should have been taught to solve problems, make a decision, adapt, create, and innovate. These skills are needed to achieve better learning outcomes.

Based on the facts, the findings of learners' living-environment knowledge and their living environment behaviors were supported by previous studies, such as Alpusari (2013), Azhar, Basyir and Alfitri (2015), Dasrita, et.al (2015) and Liao and Li (2019). They found a significant correlation between livingenvironment knowledge and living environment awareness behaviors. Thus, higher living- environment understanding led to higher livingenvironment awareness behaviors at schools and vice versa.

Then studies conducted by Hidayati, Taruna and Purnaweni (2014), Karmanto, Makmur and Hayat (2015) and Iswari and Utomo (2017) also supported and strengthened this research finding. The previous studies found that learners' active participation in various school programs to preserve the environment was an important factor in realizing a sustainable living environment. Thus, a better living environment realization was influenced by the promoted school programs to build the learners' awareness character to keep their living environments.

These finding descriptions were consistent with the social action theory of Parsons with AGIL scheme. The finding showed that adaptation function, objective, integration, and pattern maintenance in living environment education policy ran excellently and supported each other. As external factors of an education system, resources, economy, and social politics in Brebes had proper roles and supported the schools to carry out the living environment concept. During the program implementation process, it was assisted by external factors such as communication, response, attitude, and proper quality of each executive team and school member to carry out the policy. The school programs should be empowered so that the learners' living environment behaviors could be instilled properly for the present days or for the future.

\section{CONCLUSION}

The living environment education policy was seen from the basic scope and the policy objective, the communication among executive agencies, the agencies' characteristics, the socioeconomic and political situations, the executive tendency, and the resource capacity. All of them were running properly. There was no insisting regulation from the government that obligated educational institutions to implement the living environment education. The integration of living 
environment education and geography lesson was realized into learning administrations. Most materials of basic geography had been adjusted to be integrated. The living environment education inculcation was done directly in the learning processes. It could be seen from the excellent SHS learners' behaviors of living environment awareness, such as their understanding of environmental impacts. They also committed to keeping the environment and were ready to keep motivated and transmit their behaviors.

\section{REFERENCES}

Alikodra, H.S. 2017. "Etika Pelestarian Alam". Jurnal Himmah 1(1).

Alpusari, M. 2013. "Analisis Kurikulum Pendidikan Lingkungan Hidup pada Sekolah Dasar Pekanbaru". Jurnal Primary. 2(2):10-17.

Azhar, Basyir, M.D. \& Alfitri. 2015. "Hubungan Pengetahuan Dan Etika Lingkungan Dengan Sikap dan Perilaku Menjaga Kelestarian Lingkungan". Jurnal Ilmu Lingkungan. 13(1):36-41.

Barkatin, S. L., \& Wijayanto, H. 2016. Analisis Perilaku Pelajar Terhadap Lingkungan (Studi Kasus Pendidikan Menengah di Kabupaten Bogor). Jurnal Pengelolaan Sumber Daya Alam dan Lingkungan. 6(2).

Dasrita, Y., Saam, Z., Amin, B., \& Siregar, Y.I. 2015. "Kesadaran Lingkungan Siswa Sekolah Adiwiyata". Jurnal Dinamika Lingkungan Indonesia. 1(1):61-64.

Fadlillah, M.N. \& Supriyanto, T. 2020. Upacara Tradisi Ngasa di Dukuh Jalawastu Desa Ciseureuh Kabupaten Brebes. Jurnal Sutasoma: Jurnal Sastra Jawa. 8(1).

Guo, F., Meadows, M.E., Duan, Y \& Gao, C. 2020. "Geography pre-service teachers' perspectives on multimedia technology and environmental education." Journal of Sustainability (Switzerland). 12(17) 1-16.

Handayani, T., Wuryadi \& Zamroni. 2015. "Pembudayaan Nilai Kebangsaan Siswa Pada Pendidikan Lingkungan Hidup Sekolah Dasar Adiwiyata Mandiri".
Jurnal Pembangunan Pendidikan: Fondasi dan Aplikasi. 3(1):95-105.

Hardati, Puji. et.al. 2015. Pendidikan Konservasi. Semarang: Magnum Pustaka Utama.

Hardati. P \& Setyowati, D.L. 2018. "Potensi Sumberdaya Manusia Untuk Mendukung Konservasi Sungai di Desa Lerep, Ungaran Barat, Kabupaten Semarang". Prosiding. Seminar Nasional Geografi IX di Universitas Muhammadiyah Surakarta. Surakarta, 30 Juni 2018.

Hidayati N., Taruna T., \& Purnaweni, H. 2014. Perilaku Warga Sekolah Dalam Implementasi Adiwiyata di SMK Negeri 2 Semarang. Jurnal Pendidikan Geografi (GEA). 14 (1).

Irlansari, A., \& Hardati, P. 2019. "Pelaksanaan program adiwiyata berdasarkan komponen berbasis lingkungan". Jurnal Edu Geography. 7(3).

Iswari, R.D., \& Utomo S.W. 2017. Evaluasi Penerapan Program Adiwiyata Untuk Membentuk Perilaku Peduli Lingkungan di Kalangan Siswa (Studi Kasus SMA N 9 Tangerang Selatan dan MA Negeri 1 Serpong). Jurnal Ilmu Lingkungan. 15(1).

Jackson, L., Pang, M.F., Brown, E., Cain, S., Dingle, C., \& Bonebrake, T. (2016). "Environmental attitudes and behaviors among secondary students in Hong Kong." International Journal of Comparative Education and Development. 18 (2) : 70-80.

Karmanto, E.D.M., Makmur, M., \& Hayat, A. 2015. "Kebijakan Pengintegrasian Pendidikan Lingkungan Hidup Pada Sekolah Adiwiyata". Jurnal Administrasi Publik. 3(12):1981-1985.

Kementerian Lingkungan Hidup. 2011. Paduan Adiwiyata Sekolah Peduli dan Berbudaya Lingkungan. Jakarta: Asdep Urusan Penguatan Inisiatif Masyarakat Deputi Bidang Komunikasi Lingkungan dan Pemberdayaan Masyarakat Kementerian Lingkungan Hidup.

Liao, C., \& Li, H. 2019. "Environmental Education, Knowledge, and High School Students' Intention toward Separation of Solid Waste on Campus." International 
Journal of Environmental Research and Public Health. 16(9).

Notoatmodjo, Soekidjo. 2017. Pendidikan dan Perilaku Kesehatan. Jakarta. PT. Rineka Cipta.

Rezkita, S. \& Wardani, K. 2018. "Pengintegrasian Pendidikan Lingkungan Hidup Membentuk Karakter Peduli Lingkungan Di Sekolah Dasar". Jurnal Pendidikan Ke-SD-an. 4(2).

Setyowati, D.L., et.al. (Ed). 2014. Pendidikan Lingkungan Hidup. Semarang: Universitas Negeri Semarang
Wanchana, Y., Inprom, P., Rawang, W., \& Ayudhya, A.J.N. 2019. "A model of environmental education competency development for teachers in secondary schools." International journal of environmental \& science education. 14(9): 511-520.

Winarno, Budi. 2012. Kebijakan Publik (Teori, Proses, dan Studi Kasus). Jakarta: PT. Buku Seru.

Yli-Panula, E., Jeronen, E \& Lemmetty, P. 2019. "Teaching and learning methods in geography promoting sustainability." Journal of Education Sciences. 10(1) 